\title{
Antecedents of employee job stress: Evidence from the insurance industry in Ghana
}

\author{
Evelyn Twumasi ${ }^{a}$ and Michael Asiedu Gyensare ${ }^{b^{*}}$
}

${ }^{a}$ Department of Business Administration, BlueCrest University College, Accra, Ghana

${ }^{b}$ Department of Business Education, University of Education Winneba, Winneba, Ghana

\section{H R O N I C L E}

Article history:

Received March 5, 2016

Received in revised format June 15,2016

Accepted July 19, 2016

Available online

July 20, 2016

Keywords:

Role conflict

Role ambiguity

Work overload

Job stress

Insurance industry

Ghana

\section{A B S T R A C T}

Although job stress has become an issue of great concern over the last decades both internationally and nationally, there still remains a paucity of research in the Ghanaian insurance industry. This study therefore examined the relationship between antecedent variables (work overload, role conflict and role ambiguity) and employee job stress in the insurance industry in Ghana. Using a descriptive cross-sectional design with a survey questionnaire, 212 employees were selected to participate in the study. Pearson correlation and a two-step hierarchical regression were used to test the proposed hypotheses. Results of the analysis revealed that work overload and role conflict rather than role ambiguity were positively related to job stress. Implications for theory and practice are later discussed in the study.

\section{Introduction}

The world has become a global competitive environment, such that organizations are no longer restricted to their local market. For instance, the increased global competition puts pressure on companies to become more efficient and productive and this causes a great deal of stress among employees (Ahmad et al., 2010). Many studies have discovered that overstressed workforce may incur substantial costs to organizations and the community (Gillespie et al., 2001). Therefore, creating a better and encouraging work environment in order to actualize both individual and organizational objectives is a necessity for all kinds of organizations in the world.

Due to rapid economic growth, urbanization and popular education, the insurance industry expanded considerably in the nineteenth century, resulting in acute competitiveness and rivalry among companies (Chan, 2002 cited in Coetzer \& Rothman, 2006). The impact of this competition is felt among employees in the insurance industry by engendering general feelings of distrust, tension, and strain in

* Corresponding author.

E-mail address: magyensare@uew.edu.gh (M. A. Gyensare) 
interpersonal relations, interpersonal conflicts and coping with sustained pressure to perform (Lai et al., 2000). For instance, a research conducted by Saint Paul Fire Marine Insurance Company in the United States cited by DeFrank and Ivancevich (1998) revealed that an estimated 75 to 90 percent workers visit to physicians are stress-related. In Ghana, the passage and implementation of the Insurance Act, 2006 (Act 724) resulted in very vital changes in the structure and operations in the insurance industry. One obvious change is the significant increase in the number of insurance companies from 25 in 2006 to 42 in 2007 . Although this has resulted in keener competition, the adverse effect of the competition so far cannot be underestimated. The effects have been in the form of undercutting, unethical underwriting and marketing practices and over reliance on credit to manage the competition (National Insurance Commission Annual Report, 2010).

Despite the growing concern in the insurance industry, it appears that little or no research on job stress has been carried out so far. Much of the research that has been conducted on job stress has focused on context such as health, banking and education (Sackey et al., 2011; Abaa et al., 2013, Bedu-Addo, 1999) but not insurance which is also one of the most stressful occupation in the financial sector (Singh \& Singh, 2012). Given the growing importance of insurance to Ghana's economic growth, it is imperative to extend our understanding of the phenomenon in the insurance industry. Additionally, as advocated by some researchers (Sparks \& Cooper 1999; Narayanan et al., 1999; Jaramillo et al., 2004) the same workplace factors of stress are not consistently related to stress in all workplaces and the relationship could differ depending on the group being investigated. Therefore, examination of the relationship in specific contexts such as a particular organization, industry or sector is necessary as this would help give a better understanding of the impact of the variables to be tested. From the foregoing discussion, the study aims to examine the impact of role conflict, role ambiguity and work overload on employees' job stress in the Ghana insurance industry.

Job stress has become an overarching issue of great concern over the last few years, both internationally and nationally. According to the African Newsletter on Occupational Health and Safety (2014), job stress is the response people may have when presented with work demands and pressures that are not matched to their knowledge and abilities and which eventually challenge their ability to cope with their respective jobs. This means that job stress occurs if any characteristic of the job environment poses a threat to the individual be it under or over demand to meet his/her needs. A certain level of pressure in a business environment is desirable because it helps to motivate people and boost their energy and productivity levels. However, when the pressure individuals are under exceeds their ability to deal with, it becomes a negative rather than a positive force. For the purpose of this study the negative effect of job stress are emphasized. Although, the literature on job stress (Posig \& Kickul, 2003; Peiro et al., 2001; Fogarty et al., 2000) has established that role conflict, role ambiguity and work overload can lead to job stress and this can affect employees job and organizational outcomes (Perrewe et al., 2002), there is a paucity of similar research in Ghana and for that matter the insurance industry.

Role conflict is an important construct that contributes positively to job stress. Various studies (e.g. Sager, 1994) have found that job-related stress and role conflict are directly related. Also, Roberts et al. (1997) found a positive relationship between role conflict and job stress. This means that when individuals are required to play two or more role requirements that conflict with each other, they are likely to experience job stress. Furthermore, Lin (2013) found a positive relationship between role conflict and job stress. Thus, role conflict creates expectations that may be hard to reconcile at the workplace in the insurance industry. Additionally, the relationship between role ambiguity and job stress was examined. For instance, Schaubroeck et al. (1993) stated that role ambiguity occurs when assigned roles are not sufficiently articulated in terms of domain, methods of fulfillment and consequences of role performance. According to these researchers, role ambiguity is believed to increase stress; it is apparent that if one is unclear about activities he or she has to perform, will surely face stress in job. Other researchers like Sager (1994) also reported a positive impact of role ambiguity on job stress. Role ambiguity happens in numerous ways like inadequate information of job functions, 
vague expectations of peers and superiors and uncertainty of performance evaluation systems. These may cause employees to feel extensively stressed and eventually fail to perform their tasks as excepted (Teh et al., 2008). Again, role ambiguity involves uncertainty about aspects of the job including, but not limited to, such things as scope of responsibility and role expectations. Employees who experience role ambiguity tend to perform at lower levels than employees who have a clear understanding of job requirements and what is expected of them (Long et al., 2013). Greenhaus et al. (1987) opined that heavy workload lowers one's psychological well-being which in turn results in job stress. For example, a study by the North Western National Life Insurance Company showed that job stress is a consequence of high levels of job demands. The research also stated that many of today's workers especially those in a service-oriented firms like the insurance companies are finding their jobs more stressful than they anticipated simply because the number of working hours have increased (Froiland, 1993). The study on the basis of the preceding information tested the following hypotheses:

- Work overload has a positive relationship to job stress.

- Role conflict has a positive relationship to job stress.

- Role ambiguity has a positive relationship to job stress.

\section{Materials and methods}

\subsection{Research design}

The most appropriate design for the study was the descriptive cross-sectional survey. According to Saunders et al. (2007) information gathered in descriptive studies is directed towards the determination of the nature of the situation as it exists at the time of the study and to draw valid general conclusions from the facts discovered. The cross-sectional design was chosen because it studies the research problem at a point in time and not within a longer time frame.

\subsection{Sample and procedure}

Participants were 212 employees working for different department from 10 insurance companies in Ghana. Stratified random sampling approach was used to select the participants for the study. The stratification variable used in this study was the employees department. This is to ensure that all categories of employees from all departments are represented in the study.

\subsection{Measures}

Unless otherwise indicated, a five-point Likert scale ranging from 1(strongly disagree) to 5 (strongly agree) was used, with higher scores reflecting higher values of the constructs.

\subsubsection{Antecedent variables}

Role conflict and role ambiguity were assessed using House et al. (1983) scale. The following reliability coefficients were reported for role conflict $(\alpha=.72)$ and role ambiguity $(\alpha=.87)$ in this study. Sample item for role conflict included, "I receive incompatible requests from two or more people." Sample item for role ambiguity included, "My responsibilities are clearly defined". However, work overload was measured with the scale developed by Bacharach, Bamberger and Conley (1990). The reliability coefficient was $\alpha=.66$. A sample item of this scale included, "I don't have time to finish my job.

\subsubsection{Job stress}

Jamal and Baba (1992) nine-item scale $(\alpha=.82)$ was used to measure employees job stress. Sample items of this scale included, "I feel like I never have a day off" and "I have too much work and too little time to do it in".

2.3.3 Demographic characteristics 
Five demographic variables were included: age, gender, marital status, position and job tenure. The rationale for including these variables was that previous research (Matteson \& Ivancevich, 1999; Rashed, 2001; Roberts et al., 1997; Smith et al., 1998) has indicated their impact on job stress.

\section{Results}

\subsection{Data analysis}

Data entry was done using the statistical package for social sciences (SPSS). The analysis and statistical tests used in the research include Pearson Product Moment correlation coefficient and hierarchical multiple regression analyses. An alpha level of 0.05 was assumed for all the tests.

\subsection{Demographic characteristics}

The demographics examined were gender, age, marital status, tenure and rank. In our survey, out of the 212 employees surveyed for this study, $60.4 \%$ were males whereas $39.6 \%$ were females. This result means there were more men than women in the insurance companies used in the study. Also, the age distribution of the respondents shows that most of the employees were within the age range of 20-30 years $(58 \%)$ while $31-40$ years $(35.4 \%)$ was the next highest age range, followed by $41-50$ years and 50-60years which represented $4.7 \%$ and $1.9 \%$ respectively. As shown in Fig. 1, with regards to the marital status of the respondents, result indicated that majority of the respondents were single which represented $57.5 \%$ of the sample. Followed immediately were $40.6 \%$ married employees, $0.5 \%$ divorced employee and $1.4 \%$ employees who were living with someone. Furthermore, the number of years employees have spent in their various organizations were also examined. The result showed that employees who have spent 1-10 years with their organization were the majority and composed of 92.4\% . Employees who have spent $11-20$ years constituted $6.6 \%$ and only $1 \%$ of the sampled employees have spent 21 and above years in their organizations. Finally, the researcher was also interested in the positions of the sampled employees and the result demonstrated that of the 212 employees who participated in the study, $56.1 \%$ were officers whereas $26.4 \%$ were senior officers. Deputy Managers and Managers accounted for $8.0 \%$ and $9.4 \%$ respectively.

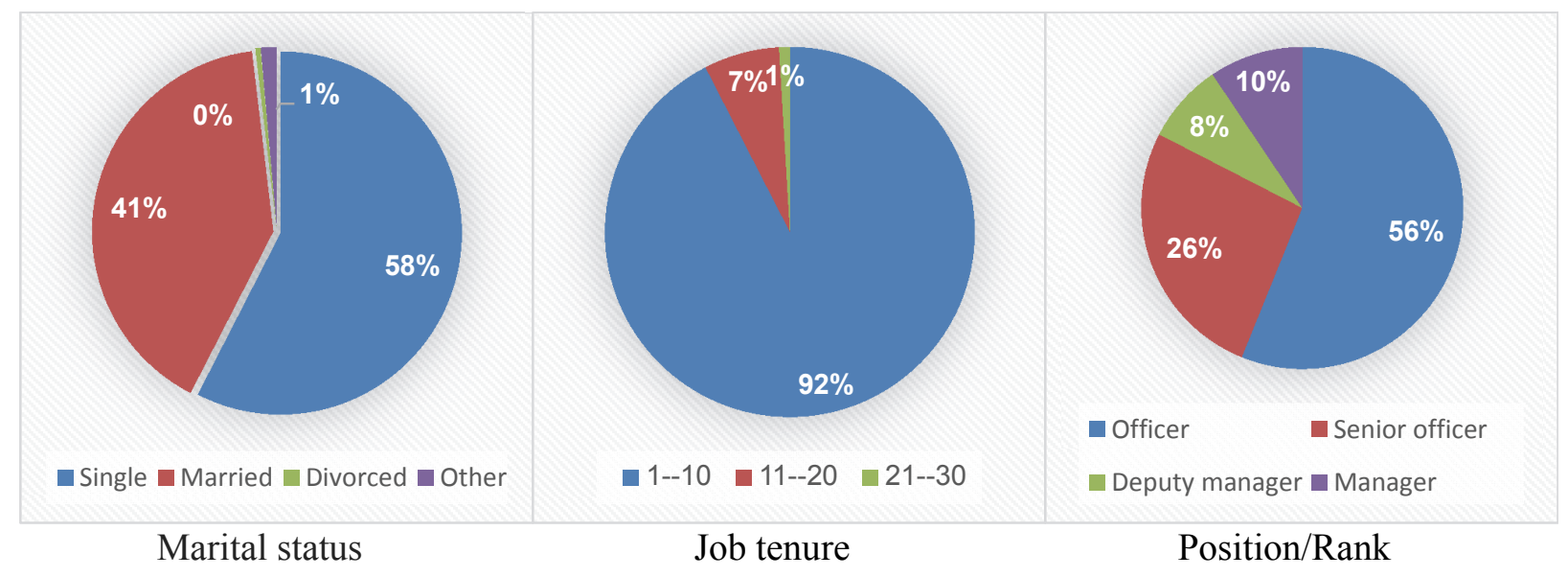

Fig. 1. Personal characteristics of the participants 


\subsection{Antecedent variables and job stress}

To test hypothesis, hierarchical regression analysis was conducted. Prior to the hierarchical regression, Pearson correlation was conducted to explore the relationship among the variables. The results in Table 2 indicated that work overload positively and significantly correlated with job stress $(r=.53, p<.01)$. Also, Table 1 showed that there is a significant positive relationship between role conflict and job stress $(r=.53, p<.01)$. Additionally, the correlation result indicated a positive relationship between role ambiguity and job $\operatorname{stress}(r=.23, p<.01)$.

Further, to allow a more sophisticated exploration of the interrelationship among the variables a twostage hierarchical multiple regression was conducted. Gender, age, marital status, tenure and position were entered at stage one to control for their effect on job stress. The antecedent variables (work overload, role conflict and role ambiguity) were entered at stage two. The hierarchical multiple regression results in Table 2 revealed that at stage one, the control variables contributed insignificantly to the regression model $F(5,206)=1.82, p>0.05$ and accounted for only $4 \%$ of the of the variance in job stress. The introduction of antecedent variables in stage two explained an additional $34 \%$ of the variation in job stress and the change in $\mathrm{R}^{2}$ was significant $F(8,203)=15.45, p<0.05$. Together, the control variables and the antecedent variables accounted for $38 \%$ of the variance in job stress.

We also assessed the unique contributions of the antecedent variables to job stress. The first variable, role conflict $(\beta=.33, p<.05)$ had the highest significant contribution followed by role overload $(\beta$ $=.30, p<.05)$. However, role ambiguity $(\beta=.10, p>0.05)$ had no significant effect on job stress. Thus, hypothesis $1 \mathrm{a}$ and $1 \mathrm{~b}$ were supported while hypothesis $1 \mathrm{c}$ was not supported.

\section{Table 1}

Zero-order correlation among study variables

\begin{tabular}{|c|c|c|c|c|c|c|c|c|c|}
\hline & 1 & 2 & 3 & 4 & 5 & 6 & 7 & 8 & 9 \\
\hline 1. Gender & -- & & & & & & & & \\
\hline 2. Age & $-.14 *$ & -- & & & & & & & \\
\hline 3. Marital status & $-.14^{*}$ & $.43^{* *}$ & -- & & & & & & \\
\hline 4. Job tenure & .02 & $.73^{* *}$ & $.38 * *$ & -- & & & & & \\
\hline 5. Position/rank & $-.14 *$ & $.46^{* *}$ & $.31 * *$ & $.40^{* *}$ & -- & & & & \\
\hline 6. Job stress & -.04 & $.15^{*}$ & $.16^{*}$ & .11 & $.16^{*}$ & .82 & & & \\
\hline 7. Role conflict & .06 & .02 & .05 & -.00 & .09 & $.53 * *$ & .72 & & \\
\hline 8. Role ambiguity & -.13 & -.04 & -.03 & -.02 & .11 & $.23 * *$ & $-.21 * *$ & .87 & \\
\hline 9. Work overload & .03 & .03 & $.23 * *$ & .06 & .11 & $.53 * *$ & $.58 * *$ & $-.25 * *$ & .66 \\
\hline
\end{tabular}

Note. $N=212 ;{ }^{*} p<0.05, * * p<0.01$ Reliability estimates are in (parenthesis) along the diagonal.

Table 2

Hierarchical regression analysis of antecedent variables and job stress

\begin{tabular}{lrrrrr}
\hline Variable & $\beta$ & \multicolumn{1}{c}{$t$-value } & \multicolumn{1}{c}{$R^{2}$} & \multicolumn{1}{c}{$\Delta R^{2}$} & $F$-statistics \\
\hline Step 1 & & & .04 & .04 & \\
$\quad$ Gender & -.00 & -.03 & & & \\
Age & .08 & .70 & & & \\
Marital status & .11 & 1.37 & & & \\
Job tenure & -.02 & -.21 & & & \\
Position & .10 & 1.30 & & & \\
Step 2 & & & .38 & .34 & \\
$\quad$ Work overload & .30 & $4.15^{* *}$ & & & \\
Role conflict & .33 & $4.80^{* *}$ & & & \\
Role ambiguity & .10 & 1.66 & & & \\
\hline
\end{tabular}

Note. $N=212 ; * * p<0.01$ 


\section{Discussion}

\subsection{Hypothesis 1: Work overload and job stress}

The result in this study showed that work overload has a significant and positive effect on job stress. Thus, employees' perceptions of workload influence their level of job stress. This finding is consistent with works done by the following researchers (Lin, 2013; Roberts et al., 1997, Miller \& Ellis, 1990). For example, in Minnesota a study by Northwestern Life Insurance Company showed that job stress is a consequence of high levels of job demand (Froiland, 1993). Similarly, Lin (2013) investigated the relationship between job demand and job stress. The correlational analysis showed that work overload correlated positively with job stress. Also, the result confirmed the Person-Environment Fit theory (Harrison, 1978) which explains that job stress occurs when the person's skills and abilities do not meet the demands of the environment. Work overload is present when there is a mismatch between an individual's abilities and demands of the job thus resulting in job stress. Therefore, the prediction that work overload would significantly influence job stress is in line with Person-Environment Fit Theory. From this finding, it could be said that when employees perceive their work load to be more than they can handle, they would experience negative emotions, fatigue and tension, thus get stressed on the job. Further, the result is consistent with a study conducted by Dollard and Winefield (1998) using the Job Demand Control Support model (JDCS) in a sample of Australian correctional officers. The researchers found that officers who had high job demands (work overload) also reported high levels of psychological distress, job dissatisfaction and physical symptoms. Again, these negative outcomes were increased when high job demands were accompanied by low job control and low levels of perceived social support.

\subsection{Hypothesis 2: Role conflict and job stress}

The result showed that role conflict influenced employees' level of job stress positively. Consistent with the researcher's expectation, employees who perceived their roles to be conflicting are likely to experience job stress at work. This result confirms findings of other researchers (e.g. Sager, 1994; Lin, 2013). For example, Schaubroeck et al. (1993) found that lack of agreement between received roles diminishes self-perception of competence and effectiveness producing frustration and anxiety on the job. Similarly, a study by Roberts et al. (1997) showed a significant positive relationship between role conflict and job stress. Also, Churchill et al. (2000) study on employees whose jobs involve direct interaction with customers or client showed that such employees would face conflicting demand from customers, supervisors and co-workers and this was a major predictor of job stress. Further, Lin (2013) also reported that role conflict significantly predicts job stress. This is to say that when employees undertake two or more role requirements that work against each other, they are likely to experience job stress.

\subsection{Hypothesis 3: Role ambiguity and job stress}

Hypothesis stated that role ambiguity would have a significant positive effect on job stress. Result from hierarchical regression analysis showed non-support for this hypothesis. This result is in discord with findings by other researchers (e.g. Teh et al., 2008; Sager, 1994; Schaubroeck et al., 1993). For instance, a recent study by Long et al. (2013) showed that role ambiguity has a significant positive impact on job stress. Similarly, research work of Teh et al. (2008) revealed that inadequate information of job functions, vague expectations of peers and uncertainty of performance evaluation systems may cause employees to feel extensively stress on the job. Researchers (e.g. Teh et al., 2008; Sager, 1994; Long et al., 2013) have concluded that organizations should try and establish clear goals for their employees because clear and specific goals regardless of their difficulty help reduce role conflict and role ambiguity. 


\section{Conclusions}

Based on these findings, it was concluded that management in the insurance companies in Ghana should pay utmost attention to work overload and role conflict in order to lessen levels of employees job stress in the insurance companies. Furthermore, management in the insurance companies must consult employees about scheduling and work rules as well as ensuring that workload is suitable to employees' abilities and resources; avoid unrealistic deadlines. This necessary as the present study found that employees in the insurance companies perceive work overload as a stressor. Lastly, the study suggests that management of the insurance companies should undertake risk analysis and provide problem focused strategies to ensure the levels of stress do not have direct impact upon the health and wellbeing of the employee; or just as importantly an indirect negative effect on the performance of the organization.

\section{References}

Abaa, R.A., Atindanbilla, S., Mwini-Nyaledzigbor P.P., \& Abepuoring, P.(2013).The causes of stress and job satisfaction among nurses at ridge and Pantang Hospitals in Ghana International Journal of Asian Social Science, 3(3), 762-771.

Addae, H.M., Parboteeah, K. P. \& Velinor, N. (2008). Role stressors and organisational commitment: public sector employment in St. Lucia. International Journal of Manpower, 29(6), 567-582.

African Newsletter (2014). Healthy workplaces-managing stress. Occupational Health and Safety, 24(1), 1-24.

Ahmad, A., Bashir, M., Humayoun, A.A. \& Mubariz, S. (2010). Impact of customer satisfaction on performance of conventional banks in Pakistan. Interdisciplinary Journal of Contemporary Research in Business, 2(8), 316-321.

Chan, K.B. (2002). Coping with work stress, work satisfaction, and social support: An interpretive study of life insurance agents. Asian Journal of Social Science, 30, 657- 685.

Churchill, G.A. J., Neil, M. E., Orvie C. W., Mark W. J., \& Tanner, J.F. (2000). Sales force management, $\left(6^{\text {th }}\right.$ ed.), Boston: Irwin McGraw Hill.

Dollard, M.F. \& Winefield, A.H. (1998). A test of the demand-control/support model of work stress in correctional officers. Journal of Occupational Health Psychology, 3(3), 243-264.

DeFrank, R. S. \& Ivancevich J. M. (1998). Stress on the job. An Executive Update in Academy of Management Executive, 12, 35 -55.

Fogarty, T. J., Singh, J., Rhoads, G. K., \& Moore, R. K. (2000). Antecedents and consequences of burnout in accounting: beyond the role stress model. Behavioral Research in Accounting, 12, 31-67.

Froiland, D. (1993). What causes job stress? Training, 30(12), 2-6.

Gillespie, N.A., Walsh, M., Winefield, A.H., Dua, J., \& Stough, C. (2001). Occupational stress in universities: Staff perceptions of the causes, consequences and moderators of stress. Work \& Stress, 15(15), 53-72.

Harrison, R. V. (1978). Person-environment fit and job stress. In C. L. Cooper \& R. Payne (Eds.), Stress at work (pp. 175-205). New York: Wiley.

House, R.J., Schuler R.S. \& Levanoni, E. (1983). Role conflict and ambiguity scales: Reality or artifacts? Journal of Applied Psychology, 68(2), 334-337.

Jamal, M. \& Baba, V.V. (1992). Shift-work and department-type related to job stress, work attitudes and behavioral intentions: A study of nurses. Journal of Occupational and Organisational Psychology, 72, 71-82.

Lai, G., Chan, K.B., Ko, Y.C. \& Boey, K.W. (2000). Institutional context and stress appraisal: The experience of life insurance agents in Singapore. Journal of Asian \& African Studies, 35, 209-228.

Lin, T. L. (2013). The relationships among perceived organization support, psychological capital and employees' job burnout in international tourist hotels. Life Science Journal, 10(3), 2104-2112.

Long C., S., Jusoh, A., Ajagbe, M. A., \& Ghee, L. C. (2013). A review on job stressor in the perspective of health care industry. Research Journal of Recent Sciences, 2(3), 81-86. 
Matteson, M. T. \& Ivancevich, J. M. (1999). Organizational behavior and management $\left(5^{\text {th }}\right.$ ed). New York: McGraw Hill.

Miller, K., \& Ellis, B.H. (1990). An integrated model of communication, stress and burnout in the workplace. Communication Research, 17(3), 27-30.

Piero, J.M., Gonzalez-Roma, V., Tordera, N., \& Manas, M.A. (2001). Does role stress predict burnout over time among health care professionals? Psychology and Health, 16(8), 511-525.

Perrewe, P.L., Hochwarter, W.A., Rossi, A.M., Wallace, A., Maignan, I., Castro, S.L., Ralston, D.A., Westman, M., Vollmer, G., Tang, M. \& Wan, P. (2002). Are work stress relationships universal? A nine-region examination of role stressors, general self-efficacy, and burnout. Journal of International Management, 8,163-187.

Posig, M., \& Kickul, J. (2003). Extending our understanding of burnout: Test of an integrated model in nonservice jobs. Journal of Occupational Health Psychology, 8(1), 3-19.

Rashed, A. A. (2001). The effect of personal characteristics on job satisfaction: A study among male managers in the Kuwait Oil Industry. International Journal of Commerce and Management, 11(3), 91-111.

Roberts, J. A., Lapidus, R. A. \& Chonko, L. B. (1997). Salesperson and stress: The moderating role of locus of control on work stressors and felt stress. Journal of Marketing Theory and Practice, 5(3), 93-108.

Sager, J.K. (1994). A structural model depicting salespeople's job stress. Journal of the Academy of Marketing Science, 22(1), 74-84.

Saunders, M., Lewis, P. \& Thornhill, A. (2007). Research methods for business students (4 ${ }^{\text {th }}$ ed.). Harlow: Prentice-Hall.

Schaubroeck, J., Ganster, D.C., Sime, W.E. \& Ditman, D. (1993). A field experiment testing supervisory role clarification. Personnel Psychology, 46, 1-25.

Steber, W. R. (1998). Occupational stress among frontline corrections workers. Menomonie: University of Wisconsin-Stout.

Teh, P. L., Ooi, K. B. \& Yong, C. C. (2008). Does TQM impact on role stressors? A conceptual model. Industrial Management \& Data Systems, 108(8), 1029-1044.

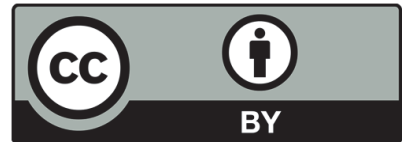

(C) 2016 by the authors; licensee Growing Science, Canada. This is an open access article distributed under the terms and conditions of the Creative Commons Attribution (CC-BY) license (http://creativecommons.org/licenses/by/4.0/). 